\title{
PERFORMANCE ANALYSIS OF STATE ELEMENTARY SCHOOL HEADMASTERS THROUGH TRAINING AND WORK ENVIRONMENT WITH MOTIVATION AS INTERVENING
}

\author{
Yuniatin Trisnawati Wardani \\ yuniatin.trisnawati@stie-aub.ac.id \\ I Gusti Putu Diva Awatara \\ STIE AUB Surakarta \\ Jl. Mr. Sartono No.97, Nusukan, Kec. Banjarsari, \\ Kota Surakarta, Jawa Tengah 57135
}

received: 3/1/18; revised: 17/12/19; published: 29/6/19

\begin{abstract}
This study aims to determine the effect of training and work environment on the performance of the heads of public elementary schools in sub-district Banjarsari of Surakarta city with motivation as an intervening variable. Methods of collecting data with questionnaires on a sample of 30 elementary school. Path analysis results conclude that: 1. The direct effect of training on performance of is greater than the indirect effect of training on performance with motivation mediation, meaning that motivation cannot function as an intervening variable. 2. The indirect effect of the work environment on motivation mediation performance is greater than the correlation between the work environment with motivation, motivation correlation with a performance, meaning that motivation cannot function as an intervening variable. 3. The total effect of training on performance is greater than the total effect of the work environment on performance. Test results concluded that to improve performance is most effective through increasing training without going through intervening variables.
\end{abstract}

Keywords: training and education; work environment; motivation; performance

\section{INTRODUCTION}

Leader is a person who must have responsibility, be able to do positive and advance the institution he leads. The responsibility of the leader is not only the physical but also the mental and moral of the employee he leads. Organizations that have good leaders will most likely become advanced organizations, and vice versa. Good or not the leader is also usually seen from the performance, achievement or output produced, not only is the process being undertaken to be good. A work process undertaken by a leader will determine the quality of performance results obtained and the output produced. In the process, the performance of a leader is influenced by various supporting factors.

In elementary school institutions, school leaders, namely principals play an important role as leaders. The Principal Performance Assessment is regulated in Permendiknas no. 13 of 2007 concerning Standards for Principals / Madrasas and Permendiknas No. 28 of 2010 concerning Assignment of Teachers as Principals in Article 12 states that: (1) Evaluation of the performance of principals/madrasas is conducted regularly every year and cumulatively everyfour years; (2) Annual performance assessments carried out by school/madrasah supervisors; (3) Four-year performance appraisal is carried out by direct supervisors by considering performance appraisal by an assessment team consisting of school/madrasah supervisors, educators, education staff, and school/madrasah committees from their place of duty; (4) The results of performance appraisal are categorized as very good, good, sufficient, moderate or lacking.

To realize good judgment and progress, performance must be maximal to reach maximum performance. The performance of principals to bring progress and good performance is influenced by various factors including education and training (training), motivation and work environment.

Minimum education for a Principal is regulated in Minister of Education Regulation No. 13 of 2007. A school principal may not be chosen randomly but must have a minimum $\mathrm{S} 1$ education criteria. Education alone is not in carrying out the duties as the principal. The number of challenges and developments and changes in the curriculum need to be followed by training in order to master the demands given. Training as "an effort to improve the performance of employees in their current work or in other jobs that they will soon occupy". Training (training) is "a systematic process to change 
the work behavior of a person/group of employees in an effort to improve organizational performance (Ivancevich, 2008). Education and training helps employees to find out their jobs better. (Deming, 1982). Employees learn from practical experience better than knowledge from books. Education and training reduce costs and save time for companies (Flynn et al., 1995; Kaynak, 2003; Heras, 2006).

Work environment according to Sedarmayati (2009) is the entire tooling equipment and materials faced, the surrounding environment in which a person works, the method of work, and work arrangements both as individuals and as a group. The working environment conditions are said to be good or appropriate if humans can carry out activities optimally, healthy, safe, and comfortable. The suitability of the work environment can be seen as a consequence in the long run the working environments that are less good can require more labor and time and do not support the obtaining of an efficient work system design. An effective work environment is an environment where results can be achieved as expected by management. (Pedler, 2010; Shikdar, 2004). The physical environment influences how employees in the organization interact, carry out work and can be directed. The physical environment as an aspect of the work environment directly affects human sensitivity and changes personal interactions to be productive. This is because the characteristics of a meeting place or room for a group can result in productivity and satisfaction levels. The work environment is the most critical factor in maintaining employee satisfaction in today's business world. Today's work environment is different, varies and changes constantly. Employee relations/traditional employers have changed. Employees live in a growing economy and have unlimited employment opportunities. These combination factors create an environment where businesses need more employees than employees need business (Smith, 2011).

Wibowo (2014) states that motivation is a driver to deal with the many human behaviors based on direction, intensity and enthusiasm to achieve goals. Job motivation and satisfaction can strengthen organizational commitment and performance. Motivation is the impulses to act through a series of human behavior by considering the direction, intensity and persistence in achieving goals. Motivation and job satisfaction can foster the strengthening of the organization's commitment and the implications on performance. Motivation is something that encourages a school principal to carry out the task as well as possible. The better the motivation possessed, the more optimistic and enthusiastic a school principal is to carry out tasks that must be completed. (Adair, 2007: 192).

The purpose or research are: 1). To find out empirically the effect of education and training on the motivation of elementary school principals in the banjarsari sub-district of Surakarta, 2). To find out empirically the influence of the work environment on the motivation of elementary school principals in the Banjarsari sub-district of Surakarta City, 3). To find out empirically the influence of education and training on the performance of elementary school principals in banjarsari sub-district, Surakarta, 4). To find out empirically the influence of the work environment on the performance of elementary school principals in banjarsari sub-district, Surakarta, 5). To find out empirically the effect of motivation on the performance of elementary school heads in the Banjarsari sub-district, Surakarta city.

\section{METHOD}

The location of the study was conducted in the Banjarsari sub-district with the object of research being the head of the Banjarsari sub-district elementary school, Surakarta city. The population consists of 60 principals. The sample of this study amounted to 30 people. The data used in this study were primary data obtained from the head of the Banjarsari sub-district elementary school Surakarta city. The technique of collecting data was done through a questionnaire to the head of the Banjarsari sub-district of Surakarta Elementary School Public Elementary School which had been selected as a sample using a Likert scale 1-5.

Measurable of variable are as follows : Training and education is an effort to change attitudes, knowledge and expertise to improve performance and service in the field of education. Education and training are measured by 1). The essence of training material is measured by indicators of how education and training are useful for improving the learning process, information about systematic, practical and coherent educational innovations, 2). Training incentives are measured by pocket money indicators and certificates, 3 ). Training facilities are measured by standard facilities and facility use indicators, 4). Training structures are measured by competency indicators and material delivery, 5). The impact of training on the learning process is measured by indicators applying the results of training and teaching materials.

Motivation is measured by indicators: 1). The need for achievement is measured by indicators of encouragement of responsibility, risk taking and high achievement. 2). The need for power is measured by indicators of challenging work, job security, freedom of work, trust in institutions to work, and respect for fellow colleagues. 3 ). The need to be affiliated/related is measured by indicators of social interaction, cooperation, recognition of ability and sportsmanship at work.

The work environment in the form of a non physical work environment is measured by: 1). Social factors are measured by indicators of family status, number of families, level of welfare. 2). The social status factor is measured by the indicator that the higher the position 
of a person the higher the authority and flexibility in making decisions. 3). Factors of work relations in organizations are measured by indicators of employment relations between employees and other employees and between employees and superiors/leaders. 4). Information system factors measured by indicators will interact, understand each other, understand each other can eliminate misunderstanding disputes.

The physical work environment is measured by 1). Work environment governance factors are measured by indicators of good working space and make it comfortable. 2). The cleanliness and neatness of the workspace is measured by indicators of a clean, neat, healthy and safe workspace.

Performance is measured by: 1). Ability is measured by indicators of material mastery, mastery of teaching methods. 2). Initiatives or initiatives are measured by indicators of positive thinking, realizing creativity, and achievement. 3). Timeliness is measured by indicators of utilization of arrival time and utilization of return time. 4). Quality of work results are measured by indicators of student satisfaction, student understanding, work performance. 5) Communication is measured from the quality indicators of material delivery, and mastery of class conditions.

Data analysis technique for testing Instrument is validity test by looking at the significance value and reliability test with cronbach alpha technique. The test results on questionnaire questions proved to be valid and reliable with the results of the validity test of the significance value $<0.05$ and the calculated $r$ value $>r$ table. The test results are proven to be entirely reliable with cronbach's alpha coefficient $>0.06$.

The hypothesis testing used are: 1 ). $t$ test to determine the significance of the effect of independent variables on the dependent variable. 2). F test to determine the effect of significance between the independent variables and the dependent variable together. 3). Analysis of the determination coefficient $\left(\mathrm{R}^{2}\right)$ to determine the contribution size of the influence of independent variables on the dependent variable. 4). Linearity test to determine linear status or not a distribution of research data. 5). Pathanalysis to determine the direct effect of one independent variable on the dependent variable, without going through another dependent variable. And to find out the indirect effect of independent variables on the dependent variable through intervening variables (intermediary variables) using Pearson correlation.

Hypotetical framework are arranged as follows: $\mathrm{H} 1=$ Training and education has a significant effect on the performance of the head of the Public Elementary School in the Banjarsari sub-district; H2 = Work environment has a significant effect on the performance of the head of the Public Elementary School in the Banjarsari sub-district; H3 = Training and Education has a significant effect on the motivation of the head of the Public Elementary School in the Banjarsari sub- district; H4 = Work environment has a significant effect on the motivation of the head of the Public Elementary School in the Banjarsari sub-district; H5 = Motivation has a significant effect on the performance of the head of the Public Elementary School in the Banjarsari subdistrict (Figure 1).

\section{RESULTS AND DISCUSSIONS}

Path analysis is done by using two equations with result 1). First equation states that training and work environment have a positive effect on motivation, if the training and work environment is increased then motivation will increase. 2). Second equation states that training and motivation have a positive effect on performance, if training is increased then performance will increase, while the work environment has a negative effect on performance, if the work environment decreases or is not good then performance will increase.

The partial hypothesis test (t-test) gets the result as follows (Table1): H1. Training and education had a significant effect on the performance of the head of the Public Elementary School in the Banjarsari sub-district (proven hypothesis), H2. The work environment has no significant effect on the performance of the head of the Public Elementary School in the Banjarsari sub-district (hypothesis is not proven). H3. Training and education has a significant effect on the motivation of the head of the Public Elementary School in the Banjarsari subdistrict (proven hypothesis). H4. The work environment has a significant effect on the motivation of the head of the Public Elementary School in the Banjarsari subdistrict (proven hypothesis). H5. Motivation has no significant effect on the performance of the head of the Public Elementary School in the Banjarsari sub-district (hypothesis is not proven).

Simultaneous test (Test - F) shows that the independent variables influence the performance of the head of the Public Elementary School in the Banjarsari sub-district. The coefficient of determination $\left(\mathrm{R}^{2}\right)$ shows the results of a total $\mathrm{R}$ square value of 0.999 which means that employee performance is explained by training and work environment with motivation as an intervening variable of $99.9 \%$ and the remaining $0.1 \%$ is explained by other variables outside the research model.

The relationship between variables (Table 2) with pearson correlation to find out the relationship between variables obtained the following results: 1 ). Training and education with employee performance is 0.990 and sig $=0.000$ means the relationship between training and performance is very strong and significant. 2 ). The work environment with employee performance is 0.565 and $\operatorname{sig}=0.001$ means the relationship between the work environment with strong and significant performance. 3 ). Motivation with employee performance is 0.637 and sig $=0.000$ means the relationship between motivation and performance is strong and significant. 4). Training 
and education with employee motivation is 0.634 and sig $=0.000$ means the relationship between training and motivation is strong and significant. 5). Work environment with employee motivation is 0.714 and $\operatorname{sig}=0.000$ means the relationship between work environment with strong and significant motivation.

The direct effect of training on performance of 0.987 is greater than the indirect effect of training on performance with motivation mediation of 0.888 and has a very strong correlation, so that to improve employee performance direct paths are chosen (Table 3 ). It can be said that motivation cannot function as an intervening variable between training and employee performance.

Indirect influence of work environment on motivation mediation performance is -0.030 and the correlation between work environment with strong motivation is $(0.714)$ and motivation correlation with strong performance is $(0.637)$ smaller than the direct effect of work environment on performance of -0.030 and has a correlation amounting to 0.565 , so that to improve the performance of employees the direct line is chosen. It can be said that motivation cannot function as an intervening variable between work environment and employee performance.

The total effect of training on performance of 0.888 has a greater effect than the total effect of the work environment on performance by 0.0144 . So as to improve performance more effectively through training improvement.

\section{CONCLUSIONS}

The direct effect of training on performance is greater than indirect influence and has a very strong correlation, so that to improve the performance of principals more effectively through direct channels. Training and education has a positive and significant effect on the performance of principals. If training is improved, the performance of the principal will increase. The direct influence of the work environment on performance is greater than the indirect influence of the work environment on performance, so that to improve the performance of employees (principals) direct paths are chosen, namely improving the work environment to improve performance. The work environment has a negative and significant effect on performance. If the work environment is improved the performance will increase. Motivation has a positive and significant effect on performance. If motivation is increased, the Head of Public Elementary School in Banjarsari District will carry out the task appropriately. The effect of training on performance is the most dominating because it has the greatest value compared to the influence of other variables on performance.

\section{REFERENCES}

Adair, Jhon. 2007. Pemimpin yang berpusat Pada Tindakan. Binarupa Aksara: Jakarta.

Deming, W.E. 1982. Quality, Productivity and Competitive Position, MIT Center for Advanced Engineering, Cambridge, MA.

Flynn, B.B., Schroeder, R.G., Sakakibara, S. 1995. The impact of quality management practices on performance and competitive advantage, Decision Sciences, Vol. 26 pp.659-91

Heras Saizarbitoria, I., Arana Landín, G. and Casadesús Fa, M., 2006. The impact of quality management in European companies' performance: The case of the Spanish companies. European Business Review, 18(2), pp.114-131.

Ivancevich, John, M, dkk. 2008. Perilaku dan Manajemen Organisasi, jilid 1 dan 2 Jakarta : Erlangga.

Kaynak, H., 2003. The relationship between total quality management practices and their effects on firm performance. Journal of operations management, 21(4), pp.405-435.

Pedler, M., 2010. Action learning for managers. Development and Learning in Organizations: An International Journal, 24(2).

Permendiknas no 13 tahun 2007 tentang Standar Kepala Sekolah / Madrasah

Permendiknas no 28 tahun 2010 tentang Penugasan guru sebagai Kepala Sekolah pada Pasal 12

Sedarmayanti.2009. Sumber Daya Manusia dan Produktivitas Kerja. Bandung: CV. Mandar Maju

Shikdar, A.A., 2004. Identification of ergonomic issues that affect workers in oilrigs in desert environments. International Journal of Occupational Safety and Ergonomics, 10(2), pp.169-177.

Smith, D.G., 2011. Work environment more important to employees. Retrieved November, 25, p.2011.

Wibowo, D.M., 2014. Effects of competence, motivation, organizational commitment to employee performance and job satisfaction of education. International Journal of Business and Management, 5(6). 
Tabel 1. Results of Conclusion of Path Regression Analysis

\begin{tabular}{clclcc}
\hline \multirow{2}{*}{ No } & Direction of & \multicolumn{2}{c}{ Regresi } & \multicolumn{2}{c}{ Correlation } \\
\cline { 3 - 6 } & Relationship & Beta & Sig & r & Sig \\
\hline 1 & $\mathrm{X}_{1}$ to $\mathrm{Y}$ & 0,987 & 0,000 & 0,990 & 0,000 \\
2 & $\mathrm{X}_{2}$ to $\mathrm{Y}$ & $-0,030$ & 0,457 & 0,565 & 0,001 \\
3 & $\mathrm{X}_{3}$ to $\mathrm{Y}$ & 0,033 & 0,446 & 0,637 & 0,000 \\
4 & $\mathrm{X}_{1}$ to $\mathrm{X}_{3}$ & 0,333 & 0,038 & 0,634 & 0,000 \\
5 & $\mathrm{X}_{2}$ to $\mathrm{X}_{3}$ & 0,521 & 0,002 & 0,714 & 0,000 \\
\hline
\end{tabular}

Tabel 2. Coeficient Correlations

\begin{tabular}{llrrrr}
\hline & & $\begin{array}{c}\text { Training } \\
\text { and } \\
\text { education }\end{array}$ & $\begin{array}{l}\text { Work } \\
\text { Enviro- } \\
\text { nment }\end{array}$ & $\begin{array}{l}\text { Motiva- } \\
\text { tion }\end{array}$ & $\begin{array}{l}\text { Perfor- } \\
\text { mance }\end{array}$ \\
\hline $\begin{array}{l}\text { Training } \\
\text { and }\end{array}$ & $\begin{array}{l}\text { Pearson } \\
\text { Correlation }\end{array}$ & 1 & $.579^{* *}$ & $.634^{* *}$ & $.990^{* *}$ \\
tion & Sig. (2-tailed) & & .001 & .000 & .000 \\
W o r k & Pearson & 30 & 30 & 30 & 30 \\
Env. & Correlation & $.579^{* *}$ & 1 & $.714^{* *}$ & $.565^{* *}$ \\
& Sig.(2-tailed) & .001 & & .000 & .001 \\
& N & 30 & 30 & 30 & 30 \\
Motiva- & Pearson & & & & \\
tion & Correlation & $.634^{* *}$ & $.714^{* *}$ & 1 & $.637^{* *}$ \\
& Sig.(2-tailed) & .000 & .000 & & .000 \\
& $\mathrm{~N}$ & 30 & 30 & 30 & 30 \\
Perfor- & Pearson & & & & \\
mance & Correlation & $.990^{* *}$ & $.565^{* *}$ & $.637^{* *}$ & 1 \\
& Sig.(2-tailed) & .000 & .001 & .000 & \\
& $\mathrm{~N}$ & 30 & 30 & 30 & 30 \\
\hline
\end{tabular}

**. Correlation is significant at the 0.01 level (2-tailed).
Tabel 3. Influence table between variables

\begin{tabular}{clccc}
\hline No & \multicolumn{1}{c}{ Variable } & $\begin{array}{c}\text { Direct } \\
\text { Influence }\end{array}$ & $\begin{array}{c}\text { Indirect } \\
\text { Effects }\end{array}$ & $\begin{array}{c}\text { Total } \\
\text { Influence }\end{array}$ \\
\hline 1 & $\begin{array}{l}\text { Training on } \\
\text { Performance }\end{array}$ & 0,987 & & \\
2 & $\begin{array}{l}\text { Work environment } \\
\text { for performance }\end{array}$ & $-0,030$ & & \\
3 & $\begin{array}{l}\text { Training through } \\
\text { motivation towards } \\
\text { performance }\end{array}$ & $0,333 \mathrm{x}-0,030$ & \\
4 & $\begin{array}{l}\text { Work environment } \\
\text { through motivation } \\
\text { towardsperformance }\end{array}$ & $0,0,099$ & \\
5 & $\begin{array}{l}\text { Tra in ing on } \\
\text { p e r f o r m a n c e } \\
\text { through motivation }\end{array}$ & $=0,0156$ & \\
6 & $\begin{array}{l}\text { Work environment } \\
\text { for performance } \\
\text { through motivation }\end{array}$ & & $0,987-0,099$ \\
\hline
\end{tabular}

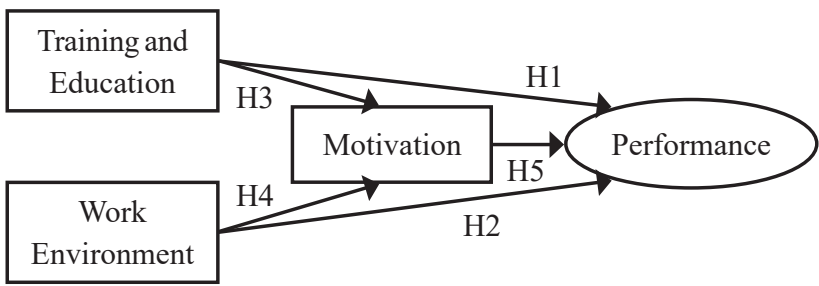

Figure 1. Research Paradigm 